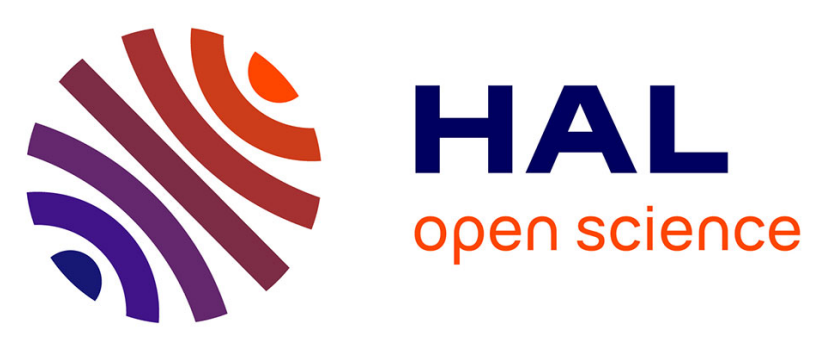

\title{
The Influence of Directed Alloying and Thermomechanical Treatment on the Structure and Mechanical Properties of High-Purity Chromium, Molybdenum and Tungsten \\ Y. Milman
}

\section{To cite this version:}

Y. Milman. The Influence of Directed Alloying and Thermomechanical Treatment on the Structure and Mechanical Properties of High-Purity Chromium, Molybdenum and Tungsten. Journal de Physique IV Proceedings, 1995, 05 (C7), pp.C7-67-C7-75. 10.1051/jp4:1995705 . jpa-00253998

\section{HAL Id: jpa-00253998 https://hal.science/jpa-00253998}

Submitted on 1 Jan 1995

HAL is a multi-disciplinary open access archive for the deposit and dissemination of scientific research documents, whether they are published or not. The documents may come from teaching and research institutions in France or abroad, or from public or private research centers.
L'archive ouverte pluridisciplinaire HAL, est destinée au dépôt et à la diffusion de documents scientifiques de niveau recherche, publiés ou non, émanant des établissements d'enseignement et de recherche français ou étrangers, des laboratoires publics ou privés. 


\title{
The Influence of Directed Alloying and Thermomechanical Treatment on the Structure and Mechanical Properties of High-Purity Chromium, Molybdenum and Tungsten
}

\author{
Y. Milman \\ Institute for Problems of Materials Science, Kiev, Ukraine
}

\begin{abstract}
The possibilities of directed alloying as well as thermomechanical treatment for improvement of the mechanical properties of high-purity chromium, molybdenum and tungsten are considered. Classification of methods of directed alloying is given. The conditions are considered of hot, warm and cold metal working as well as the peculiarities of structure formation in each temperature range.
\end{abstract}

\section{INTRODUCTION}

The flow stress of the high-purity refractory metals of Group VIA at room temperature is not very high and approximates to $400 \mathrm{MPa}$ for $\mathrm{Cr}, 415 \mathrm{MPa}$ for $\mathrm{Mo}$ and $550 \mathrm{Mpa}$ for $\mathrm{W}$. Corresponding Vickers hardness approximates to $1300 \mathrm{MPa}, 1800 \mathrm{MPa}$ and $3600 \mathrm{MPa}$ for $\mathrm{Cr}$, Mo and $\mathrm{W}$. The flow stress and hardness of high-purity refractory metals may be increased by both directed alloying (DA) and thermomechanical treatment (TMT). In both cases one has to take into account the high value of ductile-brittle transition temperature $\mathrm{T}_{\mathrm{b}}$ for these metals. The tendency to low-temperature brittleness of $\mathrm{Cr}$, Mo and $\mathrm{W}$ appears at the temperatures $T<T^{*}$, where $T^{*}$ is the so-called characteristic deformation temperature $[1-4] . T^{*}$ is the temperature at which Peierls-Nabarro stress becomes essential and decreasing the temperature lower than $\mathrm{T}^{*}$ is followed by an increase in flow stress. A sharp increase in flow stress with decreasing temperature can lead to the ductile-brittle transition phenomenon in bcc metals, as was shown by Joffe [5] and Ludwik [6] (see also [1]). In other words, $T_{b} \leq T^{*}$.

For all the metals of Group VIA, $\mathrm{T}^{*} \approx 0.2 \mathrm{~T}_{\mathrm{m}}$, where $\mathrm{T}_{\mathrm{m}}$ is the melting point, $\mathrm{K}$. More specifically, $\mathrm{T}^{*}=170,220$ and $400^{\circ} \mathrm{C}$ for $\mathrm{Cr}$, Mo and $\mathrm{W}$ [1-4]. And the lowest values of the ductile-brittle transition temperature $\mathrm{T}_{\mathrm{b}}$ for high-purity $\mathrm{Cr}$, Mo and $\mathrm{W}$ with middle value of grain size $\mathrm{d} \approx 15-20 \mathrm{~mm}$ are equal to -80 , -100 and $100^{\circ} \mathrm{C}$ at low strain rates $10^{-3}-10^{-4} \mathrm{~s}^{-1}$ if the metals have no texture. For this reason both DA and TMT for strengthening metals have to be carried out without essentially increasing $T_{b}$. The best methods of DA and TMT have to lead to decreasing $T_{b}$, but in all cases the condition $T_{b}<20^{\circ} \mathrm{C}$ must be sought.

Increasing the low-temperature plasticity of $\mathrm{Cr}$, Mo and $\mathrm{W}$ is one of the most difficult tasks, which has to be solved by using three main ways: purification of metals, DA and TMT.

The possibility of forming the necessary complex of mechanical properties in refractory metals by means of classical methods of alloying and thermal treatment is quite limited. At the same time the mechanical properties of refractory metals strongly depend on their structural and substructural state, which offers the possibility of improving their essential properties by TMT.

Although the opportunity of improving the strength characteristics of alloys by means of preliminary plastic deformation has been known for quite a long time, the physical basis of substructural strengthening 
of refractory metals is still under development at the present time. The fundamental significance of the theory of substructural strengthening was founded upon an understanding of the role of a special type of dislocation substructures - the so-called cellular (fragmented) dislocation structures, since it has been shown that formation of these structures not only enabled the strength characteristics to be increased, but also (which is of special importance) simultaneously raised the low-temperature plasticity and lowered the ductile-brittle transition temperature $\left.\mathrm{T}_{\mathrm{b}} 1,3,7,8\right]$.

In the present work a classification of refractory metal alloys into three groups depending on structural factors determining the mechanical properties is proposed:

1. low-alloyed metals and alloys with stable second phase particles;

2. alloys with unstable second phase particles;

3. high-alloyed metals with significantly changed electron structure.

The influence of TMT on structure, dislocation substructure and mechanical properties is considered for each group of alloys. Conditions of hot, warm and cold deformation as well as the peculiarities of structure formation in each temperature are considered. The boundary between the temperature ranges of cold and warm deformation is the characteristic deformation temperature $T^{*}$ and the boundary between the range of warm and hot deformation is recrystallization temperature Tr. A misoriented cellular dislocation structure is only formed by warm deformation, and conditions for TMT of refractory metals are best here.

The influence of electron structure in high-alloyed alloys (those of the third group) on stacking fault energy, Peierls stress, low-temperature brittleness, interstitial solubility and the tendency to twinning is considered.

\section{DIRECTED ALLOYING OF THE REFRACTORY METALS}

At the present time the fundamental principles of DA for the creation of alloys on the base of Group VIA metals have been established [1,7,8]. These methods of alloying have good experimental confirmation. Four methods of DA can be distinguished :

1. Alloying by highly active elements which have a great affinity for interstitial elements $(\mathrm{O}, \mathrm{C}, \mathrm{N}$ etc.). Rare earth elements and elements of groups IVA and VA (Ti, $\mathrm{Zr}, \mathrm{Hf}, \mathrm{V}$ ) are used as alloying elements, in this case in concentrations of less than 1w.p. The purification of the metal matrix by alloying is the essence of this method.

2. Alloying with small quantities (near 1w.p.) of transition metal that are situated on the right side (elements of groups VII and VIII) or on the left side (groups IV and V) to Cr, Mo and W in the Periodic Table of elements. In this case it is possible to increase low-temperature ductility and slightly raise hightemperature strength simultaneously. The positive influence of alloying elements on $T_{b}$ and low-temperature ductility is conditioned by the process of concurrent segregation of alloying elements and interstitials. As a result there is a possibility of decreasing a concentration of dangerous interstitials in boundaries of grains and subgrains as well as on dislocation lines. The influence of additions of $\mathrm{Re}$ and $\mathrm{Fe}$ on ductile-brittle transition temperature in Mo is shown in Fig. 1.

3. High alloying of $\mathrm{Cr}$, Mo and $\mathrm{W}$ with rhenium (to $50 \mathrm{at} . \%$ ) with the purpose of changing electron structure and simultaneously increasing both the low-temperature ductility and the strength in a wide temperature range. Alloys of systems $\mathrm{Cr}-\mathrm{Fe}, \mathrm{Cr}-\mathrm{Co}, \mathrm{Cr}-\mathrm{Ru}$ and some others may be placed in this group of alloys. The influence of alloying elements on the ductile-brittle transition temperature of $\mathrm{Cr}, \mathrm{Mo}$ and $\mathrm{W}$ is shown in Fig. 2.

4. Combined alloying of $\mathrm{Cr}$, Mo and $\mathrm{W}$ by elements of groups IVA (or VA) together with carbon (or nitrogen) with the purpose of increasing strength and high-temperature strength by the dispersion hardening mechanism.

Combined alloying is used in most cases that offer the possibility of utilizing some of the abovementioned principles. 

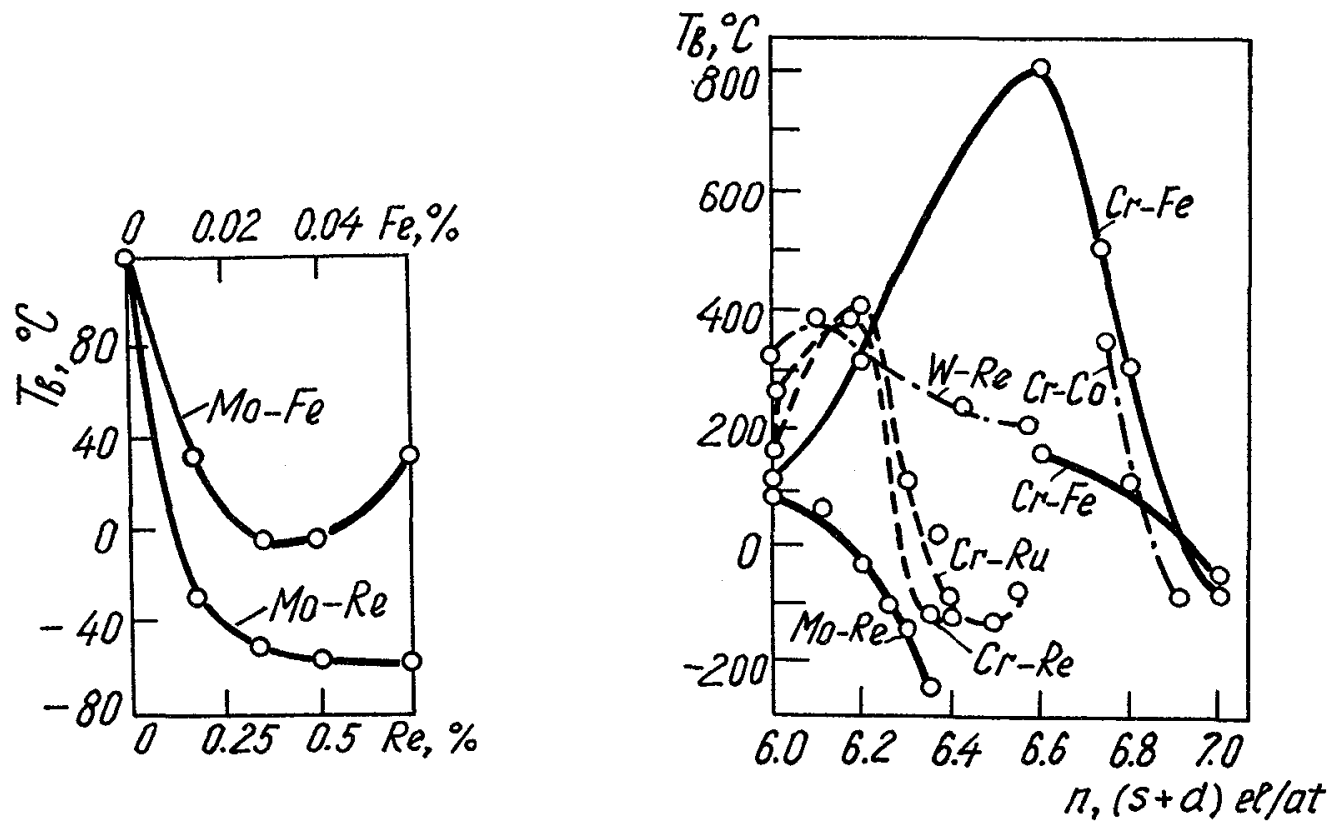

Figure 1: The influence of concentration of Re and Fe on ductile-brittle transition temperature of electron beam melted molybdenum [8].

Figure 2: The ductile-brittle transition temperature $T_{b}$ of $\mathrm{Cr}$, Mo , and W plot of concentration in the alloy of $(s+d)$ electrons per atom [1].

\section{THE INFLUENCE OF COLD, WARM AND HOT DEFORMATION ON DEFORMED METAL STRUCTURE}

Structure and dislocation substructure formation in the course of plastic deformation of metals is determined in the first instance by the temperature and degree of deformation. Hot, warm and cold deformation are accepted as distinct $[2,3,9]$. An approach to the definition of hot, warm and cold deformation has to be developed, not in connection with the necessity of metal heating or cooling but on the basis of structural changes in the deformation process (Fig. 3).

Hot deformation is plastic deformation above the dynamic recrystallization temperature. During hot deformation equiaxe grains with low dislocation density and low internal stress level are formed in a metal. Hot deformation is often used for primary working of cast metal or sintered powder billets. But during such deformation, it is unusual to succeed in forming a small-grained structure and, even more, in forming a cellular dislocation structure. The case of direct use of dynamic recrystallization may serve as an exception. In this case, equilibrium is reached between the processes of strain hardening and softening, and grain size is determined by the temperature and degree of deformation. 


\begin{tabular}{|c|c|c|c|}
\hline $\begin{array}{c}\text { Deformation } \\
\text { kind }\end{array}$ & Hot deformation & Warm deformation & Cold deformation \\
\hline $\begin{array}{l}\text { Deformation } \\
\text { temperature }\end{array}$ & $\mathrm{T}>\mathrm{T}_{\mathrm{r}}$ & $\mathrm{T}^{*}<\mathrm{T}<\mathrm{T}_{\mathrm{r}}$ & $\mathrm{T}<\mathrm{T}^{*}$ \\
\hline $\begin{array}{l}\text { Grain and } \\
\text { dislocation } \\
\text { structure }\end{array}$ & $\begin{array}{c}\text { equiaxial grain } \\
\text { structure, low } \\
\text { dislocation density } \\
\rho<10^{6}-10^{8} \mathrm{~cm}^{-2}\end{array}$ & $\begin{array}{c}\begin{array}{c}\text { non-equiaxial grain } \\
\text { structure, cellular } \\
\text { dislocation structure } \\
\mathrm{T}<0.8 \mathrm{~T}_{\mathrm{r}}\end{array} \mid \mathrm{T}>0.8 \mathrm{~T}_{\mathrm{r}} \\
\text { non-equiaxial equiaxial } \\
\text { cells }\end{array}$ & $\begin{array}{l}\text { non-equiaxial grain } \\
\text { structure, ranchom } \\
\text { dislocation structure } \\
\text { (dislocation forest) } \\
\rho>10^{8}-10^{10} \mathrm{~cm}^{-2}\end{array}$ \\
\hline $\begin{array}{c}\text { Strain } \\
\text { hardening }\end{array}$ & low or zero & $\begin{array}{l}\text { grows rapidly with } \\
\text { increase of deformation } \\
\text { to the } \varepsilon_{\mathrm{c}} \text {, than grows } \\
\text { slowly, } \varepsilon_{\mathrm{c}} \sim \sigma^{2} \text { ef } \mathrm{d} \\
\Delta \sigma_{\mathrm{s}}\end{array}$ & $\begin{array}{l}\text { grows rapidly and } \\
\text { monotonically with } \\
\text { the increase of de- } \\
\text { formation degree to } \\
\text { fracture } \\
\Delta \sigma_{S}\end{array}$ \\
\hline & & $\varepsilon_{c}$ & $\varepsilon$ \\
\hline $\begin{array}{c}\text { Fracture } \\
\text { mechanism }\end{array}$ & ductile & $\begin{array}{c}\text { ductile or } \\
\text { quasibrittle }\end{array}$ & brittle or quasibrittle \\
\hline
\end{tabular}

Figure 3 : The influence of cold, warm and hot deformation on deformed metal structure and properties.

Hence hot plastic deformation accompanied by controlled dynamic recrystallization may be used for producing extremely fine-grained metal with little variation in grain size. At lower temperatures deformation may be warm or cold. The above-mentioned characteristic deformation temperature $T^{*}$ may serve as the natural boundary between the temperature ranges of warm and cold deformation.

Recrystallization is not observed under warm plastic deformation so clearly as under cold, and initial equiaxe grain after plastic deformation becomes non-equiaxe: it elongates along the direction of tension and the specimen generally changes its shape as a whole according to the Taylor and Polanyi principle [8].

But the character of the dislocation structure formed in the course of plastic deformation significantly changes near $T^{*}$. After cold deformation $\left(T<T^{*}\right)$ a random dislocation distribution is typical, polygonization is practically absent, while under deformation $\left(\mathrm{T}^{*}<\mathrm{T}<\mathrm{Tr}\right.$ ) a celiular dislocation structure is formed after a 
certain degree of deformation $\varepsilon_{\mathrm{c}}$. This phenomenon may occur due to the fact that $\varepsilon_{\mathrm{c}} \approx \sigma_{\mathrm{ef}}{ }^{2} \mathrm{~d}$, where $\sigma_{\mathrm{ef}}$ is the effective flow stress and $d$ is the grain size [1]. Hence a sharp increase in flow stress below $T^{*}$ prevents cell structure formation, and dislocations after deformation are situated randomly. During cold deformation the dislocation density grows monotonically with the degree of deformation, and simultaneously there is a sharp increase in strain hardening and internal stresses, which may be characterized, for example, by X-ray line broadening. At the same time during warm deformation internal stresses increase with deformation up to $\varepsilon_{\mathfrak{c}}$, and then with the formation of cellular dislocation structure are practically stabilized [1,7] (see Fig. 3). The characteristic deformation temperature is also the lower temperature limit of ductile fracture.

The cell boundaries become impenetrable for gliding dislocations and begin to play the role of grain boundaries at a certain degree of plastic deformation when misorientation of neighbouring cells exceeds a critical value (according to estimation [1] $\theta_{\mathrm{c}} \approx 4^{\circ}$ for refractory metals, $\theta_{\mathrm{c}}$ depending on boundary type). In this case the formation of a misoriented cellular dislocation structure provides both increase of strength and decrease of $T_{b}$ because dislocation cells of $1 \mu \mathrm{m}$ size perform the role of grains, and a super-fine-grained metal is produced.

From Fig. 3 it can be seen that non-equiaxe grain structure is formed at any deformation temperature which is lower than $\mathrm{Tr}$. At the same time, analysis of data in the literature has shown that non-equiaxe form of the cellular structure arises at lower deformation temperatures of $T<0.8 T_{\mathbf{r}}$. In just these deformation conditions a strong tendency to metal splitting and the most clearly defined anisotropy of mechanical properties appear. If the deformation temperature is close to $T_{r}$, the phenomenon of $45^{\circ}$ embrittlement may occur $[8,12]$.

Thus, the optimum TMT temperature must be $0.8 \mathrm{~T}_{\mathrm{r}}<\mathrm{T}<\mathrm{T}_{\mathrm{r}}$. It was shown $[8,13,14]$ that the minimum value of $\mathrm{T}_{\mathrm{b}}$ and the maximum plasticity to fracture $\delta$ in Mo and $\mathrm{W}$ may be achieved if the temperature of deformation or annealing $\mathrm{T} \approx 0.95 \mathrm{~T}_{\mathrm{r}}$.

\section{THE INFLUENCE OF STRUCTURE ON MECHANICAL PROPERTIES IN VARIOUS TYPES OF ALLOYS}

While investigating the effect of structural factors on the mechanical properties of refractory metals it seems to be advantageous to divide all the alloys into three main groups and consider them sequentially (Table 1).

The influence of structural factors is studied and recognized to the highest extent for the I group. Here the main significance for improving the level of mechanical properties (i.e. increasing strength characteristics and lowering $\mathrm{T}_{\mathbf{b}}$ ) is connected with decreasing the effective grain size $\mathrm{d}_{\mathrm{ef}}$. For the recrystallized state $d_{e f}$ should be the grain size, after TMT - the cell size. For this group of alloys, the Petch relation for yield stress is satisfied :

$$
\sigma_{\mathrm{s}}=\sigma_{\mathrm{o}}+\mathrm{K}_{\mathrm{y}} \mathrm{d}_{\mathrm{ef}}^{-1 / 2}
$$

and the relation from [1] for $T_{b}$ is valid:

$$
1 / T_{b}=A-B l g d_{e f}
$$

Here $\sigma_{0}$ characterizes the resistance to dislocation moving in grain (single crystal) volume, and $\mathrm{K}_{\mathrm{y}}$ characterizes the difficulty of gliding transfer through a grain boundary and hence depends on the state of boundaries. Removal from metals of interstitial impurities is accompanied by facilitating the transfer of gliding through a grain boundary and by a reduction of $\mathrm{K}_{\mathrm{y}}$. The $\mathrm{K}_{\mathrm{y}}$ value may be decreased also by DA, according to the second principle of DA mentioned above 
Table 1.

Alloys types of refractory metals

\begin{tabular}{|c|c|c|c|}
\hline No & Alloy type & $\begin{array}{l}\text { Examples } \\
\text { (weight \%) }\end{array}$ & $\begin{array}{c}\text { Structure factors } \\
\text { determining } \\
\text { mechanical properties }\end{array}$ \\
\hline I & $\begin{array}{l}\text { non-alloyed metals, } \\
\text { low-alloyed metals and } \\
\text { alloys with stable second } \\
\text { phase particles }\end{array}$ & $\begin{array}{l}\mathrm{Cr}+0.5 \% \mathrm{Y} \\
Ц \mathrm{M}-2 \mathrm{~A} \\
(\mathrm{Mo}+0.07-0.3 \% \mathrm{Ti}+0.08- \\
0.23 \% \mathrm{Zr} \\
\mathrm{C}<0.004 \%)\end{array}$ & $\begin{array}{l}\text { size of a grain and a } \\
\text { dislocation cell (fragment), } \\
\text { density of "forest" } \\
\text { dislocations, dispersion } \\
\text { hardening by second } \\
\text { particles; } \\
\text { normal dependence of } \\
\text { mechanical properties on } \\
\text { structural factors }\end{array}$ \\
\hline II & $\begin{array}{l}\text { alloys with unstable } \\
\text { second phase particles }\end{array}$ & $\begin{array}{l}\text { Cr alloyed with } \mathrm{V}, \mathrm{B}, \overline{\mathrm{Y}} \\
(\mathrm{B} \sim 0.05 \%)\end{array}$ & $\begin{array}{l}\text { factors of the group I }+ \\
\text { dissolution of second phase } \\
\text { particles under deformation } \\
\text { strengthening; } \\
\text { anomalous dependence of } \\
\text { mechanical properties on } \\
\text { structural factors is possible }\end{array}$ \\
\hline III & high alloys & $\begin{array}{l}\text { systems Mo-Re, W-Re, } \\
\text { Cr-Fe }\end{array}$ & $\begin{array}{l}\text { change of electron structure } \\
\text { and dislocation structure } \\
\text { character, lowering the } \\
\text { stacking fault energy and } \\
\text { Peierls stress, processes of } \\
\text { solid solution dissociation }\end{array}$ \\
\hline
\end{tabular}

The $\sigma_{\mathrm{S}}$ value may be significantly increased by means of alloying or dispersion hardening and is strongly dependent on temperature below $\mathrm{T}^{*}$. At the same time the $\mathrm{K}_{\mathrm{y}} \mathrm{d}_{\mathrm{ef}} \mathrm{f}^{-1 / 2}$ dependence on temperature is much weaker, as illustrated in Fig. 4, where reduction of grain size gives almost the same increment of yield stress at all the temperatures below recrystallization temperature.

In (2), $A$ and $B$ are material constants, and $B \approx 1.5 \mathrm{k} / \mathrm{U}$, where $\mathrm{k}$ is the Boltzmann constant and $\mathrm{U}$ is the activation energy of dislocation movement. The more general expression for $T_{b}$ dependence on structural factors is given in [1]. Let us call the alloys of group I for which equations (1) and (2) are satisfied the alloys with normal dependence of mechanical properties on structural factors. TMT of these alloys is connected with cell formation and in general with decreasing $\mathrm{d}_{\mathrm{ef}}$.

It can be seen from the Fig. 5 that $\mathrm{T}_{\mathrm{b}}$ falls abruptly with a continuous increase of $\sigma_{\mathrm{S}}$ after achieving $\varepsilon_{\mathrm{c}} \approx 50 \%$, when misoriented cellular structure is formed during rolling of chromium of various purities (the purification is achieved by doping with $\mathrm{Pr}$, according to the above-mentioned first principle of DA). Moreover, the most significance is given to the fact that the $\mathrm{T}_{b}$ value after cell structure formation depends little on metal purity with respect to interstitial impurities. Lowering of deformation temperature during TMT for group I alloys causes a decrease in cell size, flow stress growth and a drop in $T_{b}$. Under annealing of deformed alloys of this group their strength characteristics fall steadily and $\mathrm{T}_{\mathrm{b}}$ grows with the annealing temperature increase because of $d_{\mathrm{ef}}$ growth due to the polygonization and recrystallization processes [1]. But the elongation at fracture $\delta$ versus annealing temperature dependence has a maximum [7]. There exists an optimum annealing temperature which provides maximum plasticity. 


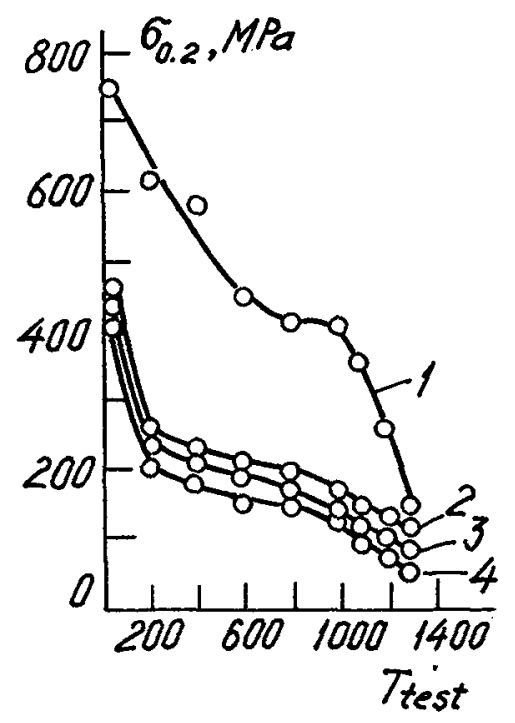

Figure 4 : Flow stress $\sigma_{0.2}$ of low-alloyed molybdenum versus testing temperature:

1 - cell structure, $\mathrm{d}_{\mathrm{ef}}=0.9 \mu \mathrm{m}$;

2,3 and 4 - recrystallized metal, $2-\mathrm{d}_{\mathrm{ef}}=24 \mu \mathrm{m}, 3-\mathrm{d}_{\mathrm{ef}}=65 \mu \mathrm{m}, 4-\mathrm{d}_{\mathrm{ef}}=150 \mu \mathrm{m}[1]$.

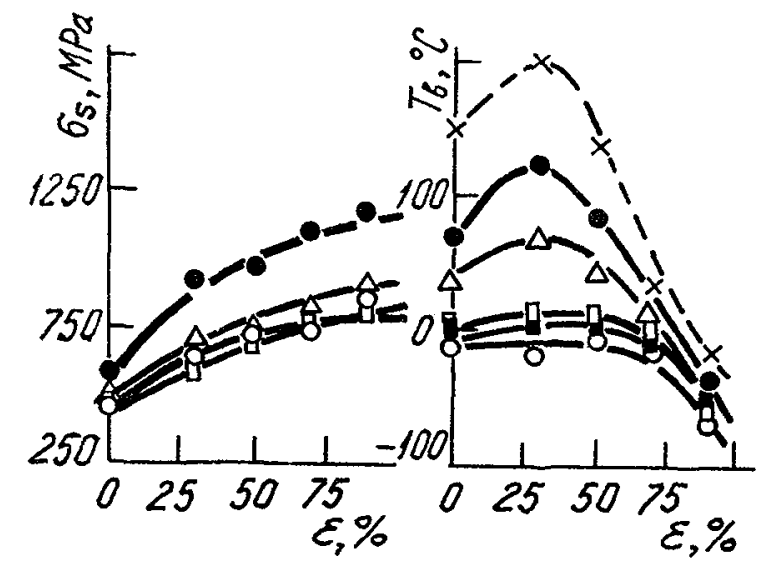

a)

b)

Figure 5 : Flow stress $\sigma_{\mathrm{S}}(\mathrm{a})$ and ductile-brittle transition temperature $\mathrm{T}_{\mathrm{b}}(\mathrm{b})$ of $\mathrm{Cr}$ and $\mathrm{Cr}$-Pr alloys versus reduction degree in rolling: - $\mathrm{Cr} ; \Delta-\mathrm{Cr}+0.25 \% \mathrm{Pr} ; \square-\mathrm{Cr}+0.5 \% \mathrm{Pr} ; \mathrm{O}-\mathrm{Cr}+1.0 \% \mathrm{Pr} ; \quad$ - $-\mathrm{Cr}+2.0 \% \mathrm{Pr} ; \mathrm{x}-\mathrm{Cr}$ coarse-grained $(\mathrm{d}=0.15 \mathrm{~mm})[7]$.

The presence of dispersed second phase particles unstable under TMT is typical for alloys from group II. Particle dissociation during plastic deformation causes solid solution supersaturation and sharp impurity segregation on dislocations and other crystal defects. Moreover strain hardening and embrittlement may be so essential that this effect influences the mechanical properties to a greater extent than decrease of grain size and cell structure formation. It was shown for low-alloyed chromium (Cr-V-B-Y) containing about 
$0.05 \% \mathrm{~B}[10]$ that anomalous growth of $\mathrm{T}_{\mathrm{b}}$ is observed by lowering the rolling temperature from 1100 to $700^{\circ} \mathrm{C}$ and decreasing grain size.

This fact was explained by boron redistribution between solid solution and segregation near lattice defects on the one hand, and borides on the other hand, and also by substantial strain hardening of chromium containing boron in segregation. Reduction of the rolling temperature causes dissolution of the borides (their size and quantity decrease) and a growth of boron content in solid solution and segregation ; thus strain hardening rises sharply. Both these factors result in increasing the ductile-brittle transition temperature in correspondence with more general theory of influence of structural factors on $T_{b}$ [1]. The effect of these factors appears to be stronger than a positive effect of decreasing the effective grain size by lowering the rolling temperature.

A special place is given to the group $\amalg$ alloys - high-alloyed chromium, molybdenum and tungsten. In the Group VIA metals the conditions of a resonance covalent bond are best fulfilled. A deep minimum corresponds to these metals in the plot of state density at Fermi level $\mathrm{N}\left(\mathrm{E}_{\mathrm{F}}\right)$. Just this kind of electron structure causes features of structure and mechanical properties specific to these metals: high stacking fault energy (SFE) and easy cross slip, high Peierls stress and sharp temperature dependence of flow stress at $\mathrm{T}<\mathrm{T}^{*}$, low-temperature brittleness, low interstitial solubility and a tendency to their segregation on crystal lattice defects.

Alloying of the Group VIA metals with rhenium and some other elements significantly changes their electron structure and thus permits an increase in both their low-temperature plasticity and their strength characteristics (Fig. 2).

The main possibilities for increasing low-temperature plasticity of the group III alloys are closely connected with electron structure change during alloying; that is, plasticity is increased when alloying essentially changes the electron structure by disturbing the optimum conditions of the resonance covalent bond and changing the filling of energy bands. The observed growth of the density of electron states at the Fermi level is accompanied by lowering of Peierls stress, decrease of SFE, increase of activation volume and interstitial solubility, and the involvement of an additional deformation mechanism - twinning.

The increase of $\mathrm{N}\left(\mathrm{E}_{\mathrm{F}}\right)$ should not be very sharp for SFE and interstitial solubility to have the optimum value. SFE has to be lowered so that twinning can occur, but the mobility of dislocation screw components should not be impeded. Lowering of SFE is accompanied by growth of activation volume and increase of stress relaxation rate at concentrators. The increase of interstitial solubility should be sufficient to diminish the tendency to impurity segregation on dislocations as well as on grain and subgrain boundaries, but not so great as to cause the abrupt hardening of a solid solution.

The effect of TMT in improving the mechanical properties of group III alloys is probably less than for the first two groups. However, a certain $\mathrm{T}_{b}$ decrease resulting from fine-grained structure formation and especially cell structure formation in W-Re as in Mo-Re alloys is in no doubt, and it is of common use in technology, e.g. for producing a wire of these alloys. During TMT of group III alloys one should also take into account the possibility of solid solution dissociation, which usually causes embrittlement and $\mathrm{T}_{\mathrm{b}}$ growth.

Thus in a wide concentration range of $\mathrm{Cr}-\mathrm{Fe}$, system annealing at $475^{\circ} \mathrm{C}$ and somewhat higher temperatures causes solid solution dissociation into two bcc phases, $\alpha$ and $\alpha^{\prime}$. The small size of creating phase particles $(\sim 100 \AA)$ sharply restricts dislocation mobility and stimulates embrittlement (so-called 475 degree brittleness). For all the alloys of group III a great danger is associated with solid solution dissociation, in the shape of $\sigma$-phase formation, which embrittles the alloys extremely.

In the alloy $64 \mathrm{at} \% \mathrm{Cr}-36 \mathrm{at} \% \mathrm{Fe}$, chromium depletion of grain boundaries was revealed by the Auger spectroscopy method [11] (Fig. 6). It was found that the iron content on grain boundaries can be raised to $68 \mathrm{at} \%$, but the chromium concentration (more than 30at\%) was sufficient to eliminate intergranular corrosion.

The width of the segregation zone was 1-5nm after the various conditions of TMT. 


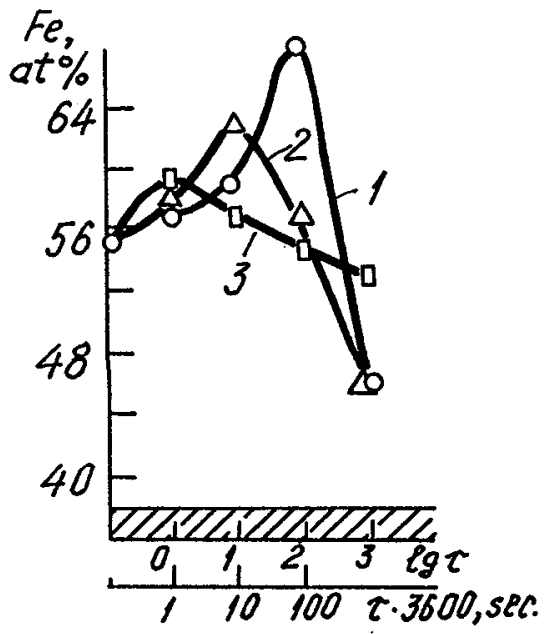

Figure 6 : Change of iron content (in at\%) on grain boundary as a function of temperature and time annealing of alloy $64 \mathrm{at} \% \mathrm{Cr}-36 \mathrm{at} \% \mathrm{Fe}: 1-475^{\circ} \mathrm{C} ; 2-600^{\circ} \mathrm{C} ; 3-700^{\circ} \mathrm{C}$; shaded region corresponds to iron content in grain volume for all heat treatment conditions [11].

\section{CONCLUSION}

The mechanical properties of refractory metals may be increased by simultaneous application of deep purification, directed alloying and thermomechanical treatment. The optimal conditions of TMT are seen from the above text, but they need to be defined more precisely for each group of alloys.

\section{Acknowledgements}

The author is grateful to Professor V. I. Trefilov (IPM, Kiev) for helpful discussions on this paper.

\section{References}

[1] Trefilov V.I., Milman Yu.V., Firstov S.A., Physical Basis of Strength for Refractory Metals, Naukova Dumka, Kiev, (1975), p.315.

[2] Gridneva I.V., Milman Yu.V., Trefilov V.I., Crystal Res. Technol. 19, 3, (1984), 413-420.

[3] Milman Yu.V. "Characteristic temperature of deformation of materials and cold brittleness of BCC metals and ceramics", Mechanics of Creep Brittle Materials - 2, Leicester, UK, 2-4 September 1991, A.C.F. Cocks and A.R.S. Ponter Eds. Elsevie d Science, (1991), pp.124-133.

[4] Galanov B.A., Grigoriev O.N., Milman Yu.V., Trefilov V.I., Ceramic and carbon-matrix composites (Chapman and Hall), London, (1995), pp.3-28.

[5] Joffe A.F., Selected works, 1, Nauka, Leningrad, (1974), (in Russian).

[6] Ludwik P., Elemente der technologyschen Mechanik, Springer, Berlin, (1990).

[7] Trefilov V.I., Milman Yu.V., Physical basis of thermomechanical treatment of refractory metals, 12th Plansee Seminar, Reutte, Austria 8-12 May, (1989), H.Bildstein, H.Ortner Eds., Metallwerk Plansee, pp.107-131.

[8] Trefilov V.I., Milman Yu.V., Ivashchenko R.K., Perlovich Yu.A., Rachek A.P. and Freze N.I., Structure, texture and mechanical properties of deformed molybdenum alloys, Naukova Dumka, Kiev, (1983), p.231.

[9] Milman Yu.V., Metallovedenie and thermotreatment of metals, 6, (1985), 2-6.

[10] Indenbaum S.V., Karsanov G.V. et. al. Izv. Akad. Nauk SSSR, Metals, 4, (1984), 161-166.

[11] Ivashchenko Yu.N., Korzhova N.P., Kurdyumova G.G. and Milman Yu.V., Phys. Met. Metall. 69,3, (1990), 123-128.

[12] Milman Yu.V., Rachek A.P., et. al. Fiz. Metal. Metalloved., 48, 2, (1979), 309-317.

[13] Karetnikov I.A., Kosachev L.S., Metalofizika, 3, 2, 85-95.

[14] Karetnikov I.A., Kosachev L.S., Milman Yu.V., Dokl. Akad. Nauk SSSR, 263, 6, (1982), 1366-1369. 